of toddlers if they eat enough to meet their energy requirement even when it is the sole source of protein (Platt, Miller \& Payne, I 96I).

Table 3. Effect of the addition of kushik on the protein value of two poor Iraqi meals

\begin{tabular}{|c|c|c|c|}
\hline Meal & $\begin{array}{c}\text { Protein } \\
\text { content } \\
(\%)\end{array}$ & $\begin{array}{l}\text { N.P.U.(op) } \\
(\%)\end{array}$ & $\begin{array}{c}\text { N.D-p.v. } \\
(\%)\end{array}$ \\
\hline Rice-okra & $8 \cdot 1$ & 59 & $4 \cdot 8$ \\
\hline Rice-okra $+15 \%$ kushik & $9 \cdot 6$ & 66 & $6 \cdot 3$ \\
\hline Parboiled wheat and 10\% chick pea & $11 \cdot 7$ & 57 & $6 \cdot 7$ \\
\hline Parboiled wheat and $10 \%$ chick pea $+15 \%$ kushik & $13 \cdot 1$ & 57 & $7 \cdot 5$ \\
\hline
\end{tabular}

Kushik can be stored for a long time. It not only improves the protein value of the two cereal diets and their palatability, but it also increases their content of B vitamins and calcium. At the present time kushik is produced in the home for family use only. The establishment of small factories in a village or group of villages, where there is an abundance or even a surplus of milk, as well as in areas where the supplies fluctuate from season to season, could make it more widely available. The availability of supplies of such a stable milk product at a low price in areas with an inadequate milk supply could contribute towards the solution of the problem of malnutrition in the country.

\title{
REFERENCES
}

Adolph, W. H. (1954). F. Amer. diet. Ass. 30, 753.

Al Witry, H., Shaby, J. \& Kantarjian, A. D. (1950). F. Fac. Med. Iraq, 14, 143.

British Medical Association: Committee on Nutrition. (1950). Report of Committee on Nutrition. London: British Medical Association.

Demarchi, M. (1958). Amer. F. clin. Nutr. 6, 4r5.

FAO (1958). Yearbook of F.A.O. 1957. Rome: Food and Agriculture Organization of the United Nations.

Frankul, W. \& Pellett, P. L. (1959). Proc. Nutr. Soc. 18, xxxvii.

Gounelle, H. \& Demarchi, M. (r953). F. Fac. Med. Iraq, I7, 42.

Gounelle, H., Demarchi, M., Rabii, H., Rashid, R., Findakly, S., Selloumi, H. F. \& Cofman, S. (1956). Bull. Soc. Sci. Hyg. Aliment., Paris, 44, 269.

Iraq Ministry of Health. (1958). Annual Report.

Jalili, M. A. \& Demarchi, M. (1952). Ұ. Fac. Med. Iraq, I6, 7 I.

Jalili, M. A., Georges, F. \& Fadhil, A. S. (1950). F. Fac. Med. Iraq, 14, 98.

Platt, B. S., Miller, D. S. \& Payne, P. R. (196r). In Recent Advances in Human Nutrition [J. F. Brock, editor.] London: Churchill.

Salman Taj El Din \& Al Jawad, J. (1956). Y. med. Prof. Baghdad, 5, 69.

Stacy, R. S. (r 944$)$. Trans. R. Soc. trop. Med. Hyg. 27, 367.

Van Veen, A. G. (1957). Formented Protein Rich Foods. F.A.O. 57/3/1966.

\section{Problems and some solutions: Pakistan}

By S. Maqsood Ali, Human Nutrition Research Unit, National Institute for Medical Research, The Ridgeway, Mill Hill, London, N.W.7

The large variety of hot, highly flavoured and sweet dishes in a Pakistani Restaurant may give casual observers a rosy picture of the dietary of the country. 
But a closer examination of data on food supplies and consumption indicates a different situation. Total food supplies available per head of the population for I 954-7 calculated from the Food Balance Sheet prepared by the Government of Pakistan (FAO, 1958) are shown in Table $\mathrm{I}$.

Table r. Pakistan : total daily food supplies/head (FAO, 1958)

\begin{tabular}{|c|c|c|c|}
\hline Food & $\begin{array}{l}\text { Quantity } \\
\text { (g) }\end{array}$ & $\begin{array}{c}\text { Calories } \\
\text { (kcal/ } \\
\text { day) }\end{array}$ & $\begin{array}{l}\text { Protein } \\
\text { (g) }\end{array}$ \\
\hline Cereals & $412 \cdot 2$ & I 468 & $32 \cdot 1$ \\
\hline Sugar & $41 \cdot 5$ & 148 & 0.3 \\
\hline Pulses and nuts & $24 \cdot 4$ & 84 & $5 \cdot 4$ \\
\hline Vegetables & 48.8 & II & 0.7 \\
\hline Fruit & $90 \cdot 9$ & 52 & 0.5 \\
\hline Meat & $12 \cdot 6$ & 24 & $x \cdot 7$ \\
\hline Fish & 0.5 & 5 & 0.7 \\
\hline Eggs & 0.9 & 2 & 0.1 \\
\hline Milk (liquid) & $\mathrm{r} 59 \cdot 2$ & 125 & $5 \cdot 8$ \\
\hline Oils and fats & $9 \cdot 6$ & 85 & - \\
\hline Total & & 2004 & $47 \cdot 3$ \\
\hline
\end{tabular}

The total food supplies provided about $2000 \mathrm{kcal} /$ head daily, $73 \%$ of the total calories was obtained from cereals, $7 \cdot 4 \%$ from sugar and $4.2 \%$ from pulses. Meat, fish and eggs together provided only $\mathrm{I} \cdot 5 \%$ and oils and fats $4.2 \%$.

In preparing food balance sheets, account is taken of wastage between source and retail level, but no allowance is made for kitchen waste. In the absence of any local information, FAO: Committee on Calorie Requirements (1957) have suggested that the latter should be taken as $10 \%$. When such an allowance is made the calorie value of the food supplies is reduced from 2000 to 1800 . The general conclusion is that the Pakistani diet is short of calories, protein, especially animal protein, and low in fats. It may also be deficient in some vitamins and minerals, partly as a result of a low consumption of vegetables.

In order to reach a more accurate assessment of the dietary, an investigation is being made of composite diets resembling those consumed in East and West Pakistan, which are based on rice and wheat respectively, and some common meals of different socio-economic groups in the country. Estimation of net dietary-protein value (N.D-p.v.), which represents the utilizable protein in the diet and reflects both quantity and quality (Platt \& Miller, 1959), showed that none of the diets, as judged by the recommendations on protein requirements put forward by the Food and Agricultural Organization (FAO: Committee on Protein Requirements, 1957), is suitable for toddlers, adolescents, or women during pregnancy and lactation. According to Platt \& Miller (I959), a food combination with N.D-p. Cals $\%$ of $7 \cdot 8,8 \cdot 0$ or 9.5 respectively, will meet the protein requirements of these groups. The results of assays of some of the diets are shown in Table 2.

In these assays the rats were fed ad lib. In practice, in the Pakistani diet the values may be on the generous side since on the average the people of Pakistan do not eat enough food to meet their full calorie requirements. Further investigations in which the test diets were given at different levels of calorie intake have shown a gradual 
reduction of N.D-p. Cals \%; this is to be expected, since with lower calorie levels the limited amount of protein in the diet is utilized to meet the energy needs of the body. When allowance is made for shortage of calories, therefore, the protein value of the diet of growing children and mothers is not satisfactory. Low birth weights and the high infantile mortality in Pakistan are no doubt to a large extent the result of bad nutrition of women during pregnancy and lactation. If the undernourished infant is weaned on to a low-protein, starchy diet, it will develop protein malnutrition.

\section{Table 2. Protein value of some Pakistani diets and meals}

\begin{tabular}{lccc}
\multicolumn{1}{c}{ Diet or meal } & Protein Cals. $\%$ & N.P.U.(op) $(\%)$ & N.D-p. Cals. \% \\
East Pakistani diet & $9 \cdot 0$ & 59 & $5 \cdot 3$ \\
West Pakistani diet & $13 \cdot 3$ & 51 & 6.8 \\
Rice-pulse-fish-vegetable curry meal & $11 \cdot 6$ & 57 & 6.6 \\
Wheat-pulse-meat curry meal & $14 \cdot 5$ & 52 & $7 \cdot 5$ \\
Rice-pulse-vegetable curry meal & $10 \cdot 4$ & 63 & 6.6 \\
Wheat-pulse-vegetable curry meal & $14 \cdot 2$ & 52 & $7 \cdot 4$ \\
Rice-pulse meal (khichri) & $9 \cdot 6$ & 66 & 6.3
\end{tabular}

The situation may be examined in the context of the increase in food production proposed in the Second Five Year Plan of the Government of Pakistan. Qureshi (rg60) compared the present national diet with that based on the planned increases and showed that, if the plans are achieved, the average diet of the Pakistani at the end of the 5 years will be higher in energy value but lower in protein content than at present. This finding points out the importance of an adequate knowledge of food science in planning the dietary of the country to meet the needs of the population.

The main problem in Pakistan is that of protein malnutrition, especially in young children and expectant and nursing mothers. In East Pakistan there is also deficiency of minerals and vitamins owing to the high preponderance of rice in the diet and to bad cooking practices. These deficiencies can be remedied by the provision of more protein, especially from animal sources; the education of the people in better methods of cooking; greater consumption of green, leafy vegetables; and improved methods of food preservation to increase the availability of protein-rich foods and vegetables. At certain times of the year a glut of vegetables occurs and in some areas of N.W. Pakistan meat is available in considerable quantities throughout the year; indeed, in some places meat provides as much as $25 \%$ of the total calories. Food preservation could spread supplies of such foods beyond the seasons of abundance as well as helping in their distribution to places where they are not available or are in short supply. Indigenous methods of food preservation are largely limited to the making of pickles and the sun-drying of a few vegetables. A good deal of fish is sun-dried and salted, mainly for export. The development of big food industries will be possible only when sufficient knowledge and appropriate techniques have been acquired, a general rise in the standard of living has taken place, and there is a new generation ready to consume processed foods. A foodstuff prepared in such a manner that it resembles a product already familiar to the consumer stands a better chance of being widely accepted than one which is quite foreign to the people's taste and which requires for its manufacture elaborate and expensive machinery.

20 (2) 3 
With this end in view, I prepared vegetables and meat by a vacuum oil dehydration plant developed and patented by the Human Nutrition Research Unit (Platt \& Heard, 1944). The process was found to be satisfactory since the products are attractive and there was little deterioration in the quality of the protein and only small losses of vitamins (Pellett, 1958). A residue of $25-30 \%$ of oil remains in the processed material; if desired, the amount can be reduced by pressing. Some other merits of the process are: (I) enzymes are rapidly destroyed by the initial immersion in hot oil, thus steam or water blanching which results in some loss of water-soluble nutrients can be avoided; (2) relatively low temperatures are used throughout the process, thus heat damage of the material is reduced; $(3)$ the material reconstitutes readily to produce a tender and palatable product.

The addition of spices would improve the products by bringing them nearer to Pakistani tastes and the spices may also help by acting as preservatives. Table 3 shows

Table 3. Effect on Pakistani diets of supplementing them with vacuum-oil dehydrated meat or fish

\begin{tabular}{|c|c|c|c|}
\hline Diet* & Protein Cals. $\%$ & N.P.U.(op) $\%$ & N.D-p. Cals. $\%$ \\
\hline East Pakistani diet: alone & 9.0 & 59 & $5 \cdot 3$ \\
\hline$+3.4 \%$ fish & II $\cdot 7$ & 62 & $7 \cdot 3$ \\
\hline$+3 \%$ meat & $I I \cdot O$ & 64 & $7 \cdot 0$ \\
\hline West Pakistani diet: alone & $13 \cdot 3$ & 51 & 6.8 \\
\hline$+3.4 \%$ fish & $\times 5 \cdot 6$ & 65 & IO.I \\
\hline$+3 \%$ meat & $14 \cdot 9$ & 64 & $9 \cdot 5$ \\
\hline
\end{tabular}

*Supplement on a fat-free, dry-weight basis.

that meat and fish dehydrated by this process, incorporated into East and West Pakistani diets, raised the values for N.P.U. and N.D-p. Cals \%. Thus, the two diets can be improved by the inclusion of $3 \%$ and $3.4 \%$ vacuum dehydrated meat and fish respectively, and the West Pakistani diet when improved in this manner is suitable for growing children and pregnant and lactating women. Dehydrated vegetables and meat could also be used as the basis of school meals and in emergency rations for the army.

\section{REFERENCES}

FAO: Committee on Calorie Requirements. (1957). F.A.O. nutr. Stud. no. 15.

FAO: Committee on Protein Requirements. (1957). F.A.O. nutr. Stud. no. I6.

FAO (1958). Food Balance Sheets (1954-56 Average). Rome: Food and Agriculture Organization of the United Nations.

Pellett, P. (1958). Proc. Nutr. Soc. 17, xliii.

Platt, B. S. \& Miller, D. S. (1959). Proc. Nutr. Soc. 18, vii.

Platt, B. S. \& Heard, C. R. C. (1944). British Patent no. 5826 I I.

Qureshi, R. U. (1960). A study with observations on laboratory animals, of some nutritional properties of predominantly plant food products with special reference to Pakistani dietaries. Ph.D. Thesis, University of London. 